\section{Dear Mary}

\author{
by Mary Annas
}

Dear Mary is a monthly feature in which readers can ask about any nursing care issue that concerns them. Answers will be supplied by Mary Annas or a consulting nurse, physician, lawyer, or ethicist where appropriate. Readers are also invited to comment on the answers.

The following letter is typical of a number of comments, both written and verbal, received by the editors concerning Dear Mary. These comments are deeply appreciated since they reflect concern among our readers for Nursing Law \& Ethics to establish standards of high quality. The editors, of course, share this concern and believe that Dear Mary, like the rest of this newsletter, must be responsive to the needs of our readers. Accordingly, over the past months many of the letters received by Ms. Annas have been referred to health care or legal experts for responses. In addition, the editors and Ms. Annas have encouraged readers to respond concerning the issues raised in the column, to effect our original purpose of providing a sounding board for nurses to exchange ideas about the many difficult issues they confront.

Although the letter below is addressed to me, I have asked Ms. Annas to respond as well.

JLG.

Dear Ms. Greenlaw:

I am writing to express my concern about one aspect of the new publication, Nursing Law and Ethics. The section entitled "Dear Mary" is not consistent with the quality and the stated purpose of the publication.

To begin with, the format rather implies a "cookbook" approach in which women (all the letters are signed with women's names) can ask questions; then, some repository of knowledge will "sympathize" and tell them how to act.

Unfortunately, the implications of the format become a reality. The answers do not provide a basis for rational deliberation. Rather, they respond to the emotional component and reflect the values and interpersonal style of the writer. Is this not in direct conflict with the point made earlier in the publication, that is, the need to move away from "simple notions and emotional reactions" and toward "reasoned discussion and analysis?"
An appropriately titled section for readers to present situations and to receive scholarly responses (not answers) from experienced professionals would be more consistent with the stated purpose of the publication. It would not only allow nurses as well as students to present ethical problems in nursing practice, but also would highlight the complexities of these problems and the process necessary to reach the best answers. Ongoing debate among readers would undoubtedly occur.

Systematic reflection on the legal and ethical dimensions of health care is a prerequisite to achieving quality patient care. Therefore, any demonstration of undisciplined reasoning to students and our nursing colleagues is regrettable.

Sincerely,

Constance T. Donovan,

R.N., M.S.N., F.A.A.N

Assistant Professor

Clinical Nurse Specialist, Cancer

Yale University School of Nursing

New Haven, Conn.

\section{Dear Readers:}

Many of Ms. Donovan's comments, and others I have received, are welltaken. Most, however, reflect only the contents of DEAR MARY in the January issue. In that issue I indicated that other relevant health care professionals would be called upon to answer questions outside the area of my own expertise or experience. Since then comments and answers from either of my co-editors, or outside legal advisers, have appeared regularly in this column. Moreover, I invite and strongly urge all our readers to comment on the issues raised in DEAR MARY and let others know about their views and concerns. The purpose of this feature is to promote discussion, not to stifle it.

It is therefore of real concern to me that since the conception of DEAR MARY, the majority of comments have been about the title of the column rather than the content. Since the title is mine and something that I thought Nursing Law \& Ethics needed (i.e.. something a little lighter, not in substance, but in the way that the material was presented in title), I feel that I need to respond to these comments.

The majority of negative comments about the title have been from graduate nurses, and the positive comments have been, except for one nurse from the National League for Nursing, from students. My first reaction, since the column is intended for students too, was to say "too bad." There is little enough humor in nursing, and if the title Dear Mary can make someone smile, so much the better.

Then I started to realize that what was happening was that nurses were not focusing on the issues at all, and this was not the intent of the column. So I have decided that I am open to suggestions as to what nurses would consider a "professional" title. Please feel free to write me with suggestions for names for the column.

\section{Dear Mary,}

While on med-surg rotation I made an error in a patient's chart, and I did something that I'm now wondering about. When I told my instructor about the error she gave me a bottle of white eraser liquid and told me to go over what I'd written, and correct it. The error was a minor one - I had written my Assessment before the Objective in my SOAP note. Do you think that this is legal and would you have done the same thing?

$$
\begin{aligned}
& \text { Betty } \\
& \text { Minneapolis, Minn. }
\end{aligned}
$$

\section{Dear Betty,}

I would not have done this had I been in your place, however I do understand the pressure students are under when an instructor tells them to do something. I think this pressure is similar to the pressure of "standing up" to a physician when you know that you are right and she/he is wrong.

At the three hospitals that I've worked at the policy has been that, if an error is made, one line should be drawn through the error (so that it is still discernable), it should be initialed by the person who wrote it, and then the correction made. I would much prefer this to the method your instructor used because regardless of the seriousness of the error, people should be able to see it rather than wondering what was under the erasure.

One of the few legallessons most health professionals have learned is never alter a medical record. This is excellent advice, since a jury will generally consider an altered medical record as the equivalent of admitting negligence. Nevertheless, like almost every "rule," this one has some obvious exceptions: the most obvious is when the record itself is incorrect. There have been many suggestions concerning record alteration. Perhaps the most widely recommended is the one suggested by Mary Annas. Such a procedure both maintains the integrity (Continued on page II) 
If the doctor's order involves a significant departure from the official labeling or involves a drug which the FDA has not approved for any purpose, the nurse should make her own independent judgment as to whether the medication order is appropriate. She should contact the hospital pharmacist and prescribing doctor, and she should chart the procedure, indicating additionally that she spoke with the hospital pharmacist and the doctor, their names, and what they said and what she did to determine the order's propriety.

2. When administering new drugs for research, the nurse, in addition to the above, must find out whether an IRB has approved the research and a written statement of informed consent, and whether the statement was signed by the patient. She should make an independent determination that the patient understands that he is a research subject who is receiving an investigational new drug, and the risks, benefits and alternatives.

These actions protect both the patient and the nurse.

\section{References}

1. N.Y. EdUC. LAW (McKinney) Art. 139, $\S 6902$.

2. Mass. Gen. Laws Ann. Ch. 112; $\$ 80 \mathrm{~B}$.

3. Mass. Gen. Laws Ann. Ch. 94C 81.

4. 21 U.S.C. $\$ 321(\mathrm{~g})$ and (p) (Federal Food, Drug, and Cosmetic Act, $\$ 201(\mathrm{p})$ and (g)(l).

5. 21 C.F.R. $310.3(\mathrm{~h})$

6. Mundy GR, Flechenstein L, Mazzullo JM, Current Medical Practice and the Food and Drug Administration: Some Evidence for the Existing Gap, JoURNAL OF THE AMERICAN MEDICAL ASSOCIATION 229(13):1744 (September 23, 1974).

7. Erichson SH, Bergman JJ, Schneeweis R, Cherkin DC, The Uses of Drugs for Unlabeled Indications, JOURNAL OF THE AMERICAN MEDICAL ASSOCIATION 243(15):1543 (April 18, 1980).

8. See Jotkowitz S, Package Inserts and FDa Policy, New England Journal of MEDICINE 298(15):856 (April 13, 1978).

9. 37 Fed. Reg. 16503, 16504 (Aug. 15, 1972) Notice of Proposed Rule Making by the FDA.

10. 42 U.S.C. \& 2891-3(a) (National Research Act of 1974); 45 C.F.R. 46; 21 U.S.C. \$505(i); 21 C.F.R. 312.

11. N.Y. Controlled Substances Act, N.Y Pub. Health Law (McKinney) Article 33, $\$ 3304$.

12. Mass. Gen. Laws Ann. Ch. 94C, $\$ 8(i)$

\section{Trageser Continued}

that Trageser did not focus on the remedial purpose of section 504 to provide broad protections to handicapped individuals. Nor had the court considered the legislative history of the Act and its subsequent amendments which, in Justice's view, reflected "the continuing congressional concern for the employment problems of the handicapped. 9

\section{Conclusion}

Although the issue created by Trageser is as important as the Supreme Court's decision in Davis ${ }^{10}$ (see Nursing Law \& Ethics, Vol. 1, No. 3), Trageser does not present the complexities of Davis. Trageser seems simply a judicial mistake.

The error in Trageser can be corrected in several ways. The most obvious would be an amendment by Congress to explicitly declare that section 504 applies to employment discrimination in all programs which receive federal financial assistance. In the meantime, continued efforts can be made in other circuits to limit the application of the case. Certainly, employers receiving federal financial assistance should not rely on Trageser as a basis upon which to justify discrimination.

\section{References}

1. 462 F. Supp. 425 (E.D. Va. 1977). This analysis has benefited from research on the Trageser case undertaken by Paula Wiseman, Legal Intern for the National Center for Law and the Handicapped, Ine.

2. 29 U.S.C. $\$ 794(a)(2)$.

3. 42 U.S.C. $\$ 2000 \mathrm{~d}-3$.

4. Trageser v. Libbie Rehabilitation Center, Inc., 590 F.2d 87 (4th Cir. 1978).

5. 4 U.S. Code Cong. and Admin. News 6390-91 (1974).

6. 45 C.G.R. Subpart B.

7. 451 F. Supp. 791 (E.D. Pa. 1978)

8.

9. 44 FED. REg. 54950 (Sept. 21, 1979),

10. Southeastern Community College v. Davis, 99 S. Ct. 2361 (1979).

\section{Conference Workbooks Available}

A limited number of the workbooks prepared for the Legal Controversies in Nursing conference series are available at $\$ 10$ each. To order, send your check to: Conference Coordinator, American Society of Law \& Medicine, 520 Commonwealth Ave., Boston, MA 02215.

\section{Dear Mary Continued}

of the medical record, and permits the correction of false data. There may be cases, however, where the information is both inaccurate and damaging even if crossed out (e.g., suicide attempt, instead of accident). In such cases the incorrect information should be obliterated from the chart. A photostatic copy of the unchanged record could be maintained in a sealed file if the health care provider is concerned about possible future litigation. For a general discussion of this issue see Babin S, Changing Notes in Medical Records: A Proposal, Medicolegal News 6(1):4 (Spring, 1978).

\section{Dear Mary,}

During my rotation in the O.R. I observed an arthroscopy on a patient who had been prepared on the surgical floor prior to being transported to the operating room. I'm not sure how much teaching was done on the floor, but the patient had not been introduced to the anesthesiologist prior to the procedure and she had been under the impression that she would be "knocked out" for the operation.

What ensued was a lengthy discussion between patient and anesthesiologist and ultimately a spinal was administered. The other health care professionals were awkward and embarrassed. Would you comment? Edward Salt Lake City

\section{Dear Edward,}

First of all I think it is irrelevant how embarrassed and awkward you felt; you don't have to either identify with or feel responsible for other nurses and doctors (although I know many of us do). I think the essential point here is that a patient needs to establish a rapport with her anesthesiologist as well as her surgeon.

My opinion is that it is advisable that the anesthesiologist should see the patient prior to surgery (the day before, if possible) and discuss alternatives and offer opinions as to the kind of anesthesia she will receive. I also feel that post-op follow up by the anesthesiologist is important to assess the patient's recovery from anesthesia. Perhaps nursing administration could suggest this to the anesthesia and surgery departments. 